ISSN 0258-7122

Bangladesh J. Agril. Res. 34(1) : 75-80, March 2009

\title{
INFLUENCE OF METHOD AND DATE OF PLANTING ON THE PRODUCTION OF LETTUCE
}

\author{
P. C. D. SHARMA ${ }^{1}$, M. M. RAHMAN ${ }^{2}$, M. A. H. MOLLAH ${ }^{3}$ \\ AND M. S. ISLAM ${ }^{4}$
}

\begin{abstract}
The effect of two planting methods (direct seed sowing and transplanting of seedlings) and seven dates of planting (8 Oct., 2 Nov., 27 Nov., 22 Dec., 16 Jan., 10 Feb. and 5 March) on the production of lettuce was compared. 'Green Wave' a loose leaf Japanese variety was used. The average yield of the direct seeded crops $(17.16 \mathrm{t} / \mathrm{ha})$ was found to be almost double than that of the transplanted crops (9.08). The yields ( $\mathrm{t} / \mathrm{ha}$ ) from different dates of planting were 13.7 (8 Oct.), 15.04 (2 Nov.), 8.94 (27 Nov.), 14.54 (22 Dec.), 21.45 ( 16 Jan.) 10.16 (10 Feb.), and 8.02 (5 March). The highest yield of 24.0 t/ha was obtained from direct seedling on 16 January.
\end{abstract}

Key Words: Method, date, planting, production of lettuce.

\section{Introduction}

Lettuce (Lactuca sativa L.) is a salad crop belonging to the family Compositae. Although lettuce is the most widely grown salad crop of the world (Rashid, 1999), it is still a minor crop and little known in Bangladesh. Research based information on the production of this crop under local conditions are almost absent. There are reasons to think that lettuce will become popular in the coming years and as such, investigations to standardize the method of its production are required.

The lettuce crop is raised in two methods. In one method which is practiced in North America, seeds are sown directly in the field. In the other method, seedlings are transplanted. It is more commonly used in Europe, especially in crops grown under controlled environment (Ryder, 1998), In Bangladesh, lettuce can be grown only during the rabi season. It is very sensitive to the environmental factors. This study was carried out to compare the two methods of production and to know the effect of date of planting on the success of production and the yield and other characters of the crop.

\section{Material and Method}

The experiment was conducted at the experimental Farm of Bangabandhu Sheikh Mujibur Rahman Agricultural University (BSMRAU), Gazipur during the period

\footnotetext{
${ }^{1}$ MS Student (Horticulture), BSMRAU, Gazipur, ${ }^{2 \& 3}$ Professor and Assoc. Professor, Dept. of Horticulture and Crop Botany, BSMRAU, Gazipur, respectively. ${ }^{4}$ Senior Scientific Officer, HRC, BARI, Gazipur-1701, Bangladesh.
} 
of October 2002 to May 2003. The soil of the experimental site was sandy loan in texture and belonging to the Salna series with a $\mathrm{pH}$ of 6.5. Mean monthly maximum and minimum temperature, relative humidity and precipitation that prevailed during the experimental period are presented in Table 1.

Table 1. Monthly mean maximum and minimum temperature, relative humidity and total rainfall (mm) for October 2002 May 2003.

\begin{tabular}{|c|c|c|c|c|c|}
\hline \multirow[t]{2}{*}{ Month } & \multicolumn{2}{|c|}{ Air temp. } & \multicolumn{2}{|c|}{ RH } & \multirow[t]{2}{*}{ rainfall (mm) } \\
\hline & Max & Min & Max & Min & \\
\hline October 2002 & 31.8 & 20.5 & 97.4 & 39.4 & 62.7 \\
\hline November 2002 & 28.7 & 16.7 & 95.9 & 41.1 & 21.7 \\
\hline December 2002 & 25.5 & 12.2 & 90.8 & 44.3 & 0 \\
\hline January 2003 & 17.8 & 12.9 & 94.1 & 42.7 & 0 \\
\hline February 2003 & 23.7 & 15.9 & 97.3 & 38.7 & 7.4 \\
\hline March 2003 & 27.9 & 17.4 & 96.7 & 40.5 & 111.4 \\
\hline April 2003 & 33.2 & 23.7 & 97.5 & 40.8 & 56.1 \\
\hline May 2003 & 33.3 & 27.1 & 96.6 & 41.2 & 247 \\
\hline
\end{tabular}

Lettuce cultivar Green Wave (originated in Japan) was used as the test crop for the experiment. It is of the leafy and spreading type and stated to be heat tolerant. The experiment was laid out in split-plot design with three replications. There were two planting methods viz., direct seed sowing and transplanting and seven planting dates viz., 8 October, 2 November, 27 November, 22 December 16 January, 10 February and 5 March in the experiments. The methods were placed in main plots and planting dates in subplots. Subplot treatments were randomly assigned in each main plot. The total number of subplots was 42 . The size of each subplot was $2 \mathrm{~m} \times 2 \mathrm{~m}$. The subplots, the main plots and blocks were separated by a spacing of $0.5,0.5$, and $1.0 \mathrm{~m}$, respectively. Plant to plant distance was $20 \mathrm{~cm}$ and row to row distance was $40 \mathrm{~cm}$ in each subplot. Each plot contained 25 lettuce plants. Manures and fertilizers were applied @ cowdung 10 tons, urea $250 \mathrm{~kg}$, TSP $150 \mathrm{~kg}$, and MP $250 \mathrm{~kg}$ per hectare. Fifty percent of cowdung was applied during land preparation. The remaining cowdung, entire quantity of TSP and MP were applied during pit preparation. Urea was applied as top dressing in two equal installments at 30 and 45 days after sowing and 10 and 20 days after transplanting.

The seeds were sown in sub plots as per scheduled dates ( 25 days interval) with a row spacing of $40 \mathrm{~cm}$ and $20 \mathrm{~cm}$ within row in pit. First thinning was done after 10 days at 2-leaf stage, keeping 4-5 plants per pit; second thinning was done 8 days after the first thinning at 3-4-leaf stage keeping 2-3 plants per pit and the 
third thinning was done 7 days after second thinning keeping one plant per pit at 5-6-leaf stage.

In the case of transplanting, seeds were sown in well prepared seedbed as per scheduled dates. Germination of seeds was complete within five days. Twenty five days old seedlings were transplanted in the subplot with spacing of $40 \mathrm{~cm} \times$ $20 \mathrm{~cm}$. Irrigation along with other intercultural operations were done as and when needed. The crop was harvested at 55 days after sowing and 30 days after transplanting. Ten plants were randomly selected from each plot for collection of data. The recorded data were statistically analyzed and the means were separated by Duncun's Multiple Range Test (DMRT) for interpretation of results.

\section{Results and Discussion}

\section{Influence of planting method}

Planting method influenced the leaf yield and yield attributes significantly (Table 2). It was observed that plants from direct sowing method showed better performance over transplanting in respect of plant height $(19.78 \mathrm{~cm})$, number of leaves (15.34), leaf size $\left(332.59 \mathrm{~cm}^{2}\right)$, spread (diameter) of plants $(23.59 \mathrm{~cm})$, edible plant weight $(136.43 \mathrm{~g})$, and leaf yield per hectare $(17.16 \mathrm{t} / \mathrm{ha})$. It is obviously due to the uninterrupted growth of the plants which did not suffer transplanting shock. Ryder (1998) reported that the growth of the pruned roots and subsequent growth of the plants become slower in transplanted plants. Results indicate that nearly $100 \%$ higher yield was obtained from direct sowing compared with transplanting when harvested at the same time.

Table 2. Effect of planting method on leaf yield contributing characters of lettuce.

\begin{tabular}{l|c|l|l|l|l|l}
\hline Planting method & $\begin{array}{c}\text { Plant } \\
\text { height } \\
(\mathrm{cm})\end{array}$ & $\begin{array}{c}\text { Leaves/ } \\
\text { plant (no.) }\end{array}$ & $\begin{array}{c}\text { Broad } \\
\text { leaf area } \\
\left(\mathrm{cm}^{2}\right)\end{array}$ & $\begin{array}{c}\text { Spread } \\
\text { diameter } \\
(\mathrm{cm})\end{array}$ & $\begin{array}{c}\text { Leaf yield/ } \\
\text { plant }(\mathrm{g})\end{array}$ & $\begin{array}{c}\text { Yield } \\
(\mathrm{t} / \mathrm{ha})\end{array}$ \\
\hline Direct sowing $\left(\mathrm{M}_{1}\right)$ & $19.78 \mathrm{a}$ & $15.34 \mathrm{a}$ & $332.59 \mathrm{a}$ & $23.59 \mathrm{a}$ & $136.43 \mathrm{a}$ & $17.16 \mathrm{a}$ \\
Transplanting $\left(\mathrm{M}_{2}\right)$ & $16.14 \mathrm{~b}$ & $10.12 \mathrm{~b}$ & $242.59 \mathrm{~b}$ & $19.08 \mathrm{~b}$ & $72.73 \mathrm{~b}$ & $9.08 \mathrm{~b}$ \\
\hline F-test & $* *$ & $* *$ & $* *$ & $* *$ & $* *$ & $* *$ \\
$\mathrm{CV}(\%)$ & 4.08 & 8.76 & 5.3 & 5.36 & 9.35 & 8.04 \\
\hline
\end{tabular}

**Significant at $1 \%$ level

\section{Influence of planting date}

Planting date had significant influence on leaf yield and yield components of lettuce (Table 3). Plants from 16 January planting showed better performance in respect of plant height $(20.65 \mathrm{~cm})$, number of leaves per plant (14.60), leaf size $\left(369.79 \mathrm{~cm}^{2}\right)$, spread diameter $(27.10 \mathrm{~cm})$ and edible plant weight $(171.84 \mathrm{~g})$, 
while the lowest performance was observed in 27 November planting, which was followed by 5 March planting. Price et al. (1981) obtained $170 \mathrm{~g}$ marketable yield per plant when the crop was grown under controlled environment. The maximum leaf yield (21.45 t/ha) was obtained from 16 January planting and the second highest yield was obtained in 2 November planting (15.04 t/ha), which was statistically identical with 22 December (14.45 t/ha) and 8 October planting (13.70 t/ha). The yield of 27 November planting was lower compared to the yield of 2 November and 22 December planting. The low yield of 27 November was attributed due to very poor performance of lettuce grown from transplanting method. Again transplanting shock, lack of proper care just after transplanting and subsequent foggy weather etc. might be responsible for poor performance of lettuce grown on 27 November. It indicates that the growth of the lettuce plant is markedly influenced by the management practices, environmental factors, namely temperature, sunshine, day length etc. although relative importance of these factors cannot be estimated from the experiment. Burding and Sanchez (1990) also reported that low temperature with $14 \mathrm{hr}$ light conditions are congenial for higher yield of lettuce. The lowest yield (8.02 t/ha) was recorded in 5 March planting, which was statistically similar with 27 November planting (8.94 t/ha). Results revealed that leaf yield decreased, considerably in late planting mainly due to very high temperature (Table 1) and foggy weather at the vegetative stage. So, it can be concluded that very low and high temperature is not favourable for the normal growth of lettuce. Verkerk and Spitters (1973) also reported that the number of leaves, length, and width of largest leaf, total leaf area, and yield are affected by light energy and temperature.

Table 3. Effect of planting time on leaf yield and yield contributing characters of lettuce.

\begin{tabular}{l|l|l|l|l|l|l}
\hline \multicolumn{1}{c|}{$\begin{array}{c}\text { Planting } \\
\text { method }\end{array}$} & $\begin{array}{c}\text { Plant height } \\
(\mathrm{cm})\end{array}$ & $\begin{array}{c}\text { Leaves/ } \\
\text { plant (no.) }\end{array}$ & $\begin{array}{c}\text { Broad } \\
\text { leaf area } \\
\left(\mathrm{cm}^{2}\right)\end{array}$ & $\begin{array}{c}\text { Spread } \\
\text { diameter } \\
(\mathrm{cm})\end{array}$ & $\begin{array}{c}\text { Leaf yield/ } \\
\text { plant }(\mathrm{g})\end{array}$ & yield (t/ha) \\
\hline 8 Oct. $\left(\mathrm{T}_{1}\right)$ & $16.37 \mathrm{c}$ & $14.37 \mathrm{a}$ & $319.61 \mathrm{~b}$ & $22.82 \mathrm{~b}$ & $109.70 \mathrm{~b}$ & $13.7 \mathrm{~b}$ \\
2 Nov. $\left(\mathrm{T}_{2}\right)$ & $19.80 \mathrm{a}$ & $14.50 \mathrm{a}$ & $332.36 \mathrm{~b}$ & $22.15 \mathrm{~b}$ & $120.48 \mathrm{~b}$ & $15.04 \mathrm{~b}$ \\
27 Nov. $\left(\mathrm{T}_{3}\right)$ & $14.40 \mathrm{~d}$ & $8.88 \mathrm{~d}$ & $199.78 \mathrm{~d}$ & $17.03 \mathrm{~d}$ & $71.39 \mathrm{~cd}$ & $8.94 \mathrm{~cd}$ \\
22 Dec. $\left(\mathrm{T}_{4}\right)$ & $20.62 \mathrm{a}$ & $12.20 \mathrm{bc}$ & $327.99 \mathrm{~b}$ & $23.78 \mathrm{~b}$ & $113.09 \mathrm{~b}$ & $14.54 \mathrm{~b}$ \\
16 Jan. $\left(\mathrm{T}_{5}\right)$ & $20.65 \mathrm{a}$ & $14.60 \mathrm{a}$ & $369.79 \mathrm{a}$ & $27.10 \mathrm{a}$ & $171.09 \mathrm{~b}$ & $21.45 \mathrm{a}$ \\
16 Feb. $\left(\mathrm{T}_{6}\right)$ & $17.72 \mathrm{~b}$ & $13.72 \mathrm{ab}$ & $284.77 \mathrm{c}$ & $19.98 \mathrm{c}$ & $81.34 \mathrm{c}$ & $10.16 \mathrm{c}$ \\
5 Mar. $\left(\mathrm{T}_{7}\right)$ & $16.16 \mathrm{c}$ & $10.83 \mathrm{c}$ & $178.83 \mathrm{~d}$ & $16.45 \mathrm{~d}$ & $64.21 \mathrm{~d}$ & $8.02 \mathrm{~d}$ \\
\hline F-test & $* *$ & $* *$ & $* *$ & $* *$ & $* *$ & $* *$ \\
CV(\%) & 4.08 & 8.76 & 5.3 & 5.36 & 9.35 & 8.04
\end{tabular}

In a column, the figure(s) having same letter(s) do not differ significantly by DMRT

$* *$ Significant at $1 \%$ level 


\section{Interaction effects of planting method and planting date}

Interaction of planting method and planting date exerted significant influence on leaf yield and yield components of lettuce (Table 4). Plant height ranged from 22.77 to $11.00 \mathrm{~cm}$. The maximum height was attained by the plants in $\mathrm{M}_{1} \mathrm{~T}_{2}$ and the minimum height was attained by the plants in $\mathrm{M}_{2} \mathrm{~T}_{3}$. The highest number of leaves was found in $\mathrm{M}_{1} \mathrm{~T}_{2}$ (18.27), which was statistically identical with $\mathrm{M}_{1} \mathrm{~T}_{1}$ (18.20), $M_{1} T_{5}$ (17.07) $M_{1} T_{6}$ (15.55) and statistically different from the rest of the treatments. The plants produced the lowest number of leaves (5.89) per plant in treatment $\mathrm{M}_{2} \mathrm{~T}_{3}$. The highest leaf area was observed in $\mathrm{M}_{1} \mathrm{~T}_{5}\left(408.41 \mathrm{~cm}^{2}\right)$, which was followed by $\mathrm{M}_{1} \mathrm{~T}_{2}\left(392.53 \mathrm{~cm}^{2}\right), \mathrm{M}_{1} \mathrm{~T}_{1}\left(388.03 \mathrm{~cm}^{2}\right)$, and $\mathrm{M}_{1} \mathrm{~T}_{4}\left(302.70 \mathrm{~cm}^{2}\right)$ and the lowest was found in $\mathrm{M}_{2} \mathrm{~T}_{3}\left(129.62 \mathrm{~cm}^{2}\right)$, which was identical with $\mathrm{M}_{2} \mathrm{~T}_{7}$ $\left(163.73 \mathrm{~cm}^{2}\right)$. The highest plant diameter was obtained from $\mathrm{M}_{1} \mathrm{~T}_{5}(28.00 \mathrm{~cm})$, which was followed by $\mathrm{M}_{1} \mathrm{~T}_{1}(26.48 \mathrm{~cm})$ and $\mathrm{M}_{1} \mathrm{~T}_{4}(26.06 \mathrm{~cm})$. The lowest plant diameter was found in $\mathrm{M}_{2} \mathrm{~T}_{3}(12.10 \mathrm{~cm})$.

Table 4. Interaction effect of planting method and time on leaf yield and yield contributing characters of lettuce.

\begin{tabular}{l|l|l|l|l|l|l}
\hline Treatments & $\begin{array}{c}\text { Plant height } \\
(\mathrm{cm})\end{array}$ & $\begin{array}{c}\text { Leaves/ } \\
\text { plant (no.) }\end{array}$ & $\begin{array}{c}\text { Leaf area } \\
\left(\mathrm{cm}^{2}\right)\end{array}$ & $\begin{array}{c}\text { Spread } \\
\text { diameter } \\
(\mathrm{cm})\end{array}$ & $\begin{array}{c}\text { Leaf yield/ } \\
\text { plant }(\mathrm{g})\end{array}$ & $\begin{array}{c}\text { Yield } \\
(\mathrm{t} / \mathrm{ha})\end{array}$ \\
\hline $\mathrm{M}_{1} \mathrm{~T}_{1}$ & $18.47 \mathrm{bc}$ & $18.20 \mathrm{a}$ & $388.03 \mathrm{a}$ & $26.48 \mathrm{ab}$ & $153.74 \mathrm{~b}$ & $19.20 \mathrm{~b}$ \\
$\mathrm{M}_{1} \mathrm{~T}_{2}$ & $22.77 \mathrm{a}$ & $18.27 \mathrm{a}$ & $392.53 \mathrm{a}$ & $24.37 \mathrm{bc}$ & $163.27 \mathrm{~b}$ & $20.39 \mathrm{~b}$ \\
$\mathrm{M}_{1} \mathrm{~T}_{3}$ & $17.8 \mathrm{bcd}$ & $11.87 \mathrm{c}$ & $269.93 \mathrm{c}$ & $21.97 \mathrm{cde}$ & $125.05 \mathrm{c}$ & $15.65 \mathrm{c}$ \\
$\mathrm{M}_{1} \mathrm{~T}_{4}$ & $22.47 \mathrm{a}$ & $14.73 \mathrm{~b}$ & $372.57 \mathrm{a}$ & $26.06 \mathrm{ab}$ & $155.99 \mathrm{~b}$ & $20.32 \mathrm{~b}$ \\
$\mathrm{M}_{1} \mathrm{~T}_{5}$ & $21.83 \mathrm{a}$ & $17.07 \mathrm{ab}$ & $408.41 \mathrm{a}$ & $28.00 \mathrm{a}$ & $192.32 \mathrm{a}$ & $24.00 \mathrm{a}$ \\
$\mathrm{M}_{1} \mathrm{~T}_{6}$ & $18.89 \mathrm{~b}$ & $15.55 \mathrm{ab}$ & $302.70 \mathrm{bc}$ & $22.23 \mathrm{~cd}$ & $95.68 \mathrm{~d}$ & $11.95 \mathrm{~d}$ \\
$\mathrm{M}_{1} \mathrm{~T}_{7}$ & $16.22 \mathrm{~d}$ & $11.66 \mathrm{c}$ & $193.92 \mathrm{e}$ & $16.00 \mathrm{~h}$ & $68.92 \mathrm{e}$ & $8.61 \mathrm{e}$ \\
$\mathrm{M}_{2} \mathrm{~T}_{1}$ & $14.27 \mathrm{e}$ & $10.53 \mathrm{c}$ & $251.19 \mathrm{~d}$ & $19.17 \mathrm{efg}$ & $65.66 \mathrm{e}$ & $8.20 \mathrm{e}$ \\
$\mathrm{M}_{2} \mathrm{~T}_{2}$ & $16.83 \mathrm{~cd}$ & $10.73 \mathrm{c}$ & $272.18 \mathrm{~cd}$ & $19.93 \mathrm{def}$ & $77.69 \mathrm{de}$ & $9.68 \mathrm{~d}$ \\
$\mathrm{M}_{2} \mathrm{~T}_{3}$ & $11.00 \mathrm{f}$ & $5.89 \mathrm{~d}$ & $129.62 \mathrm{f}$ & $12.10 \mathrm{i}$ & $17.73 \mathrm{f}$ & $2.23 \mathrm{f}$ \\
$\mathrm{M}_{2} \mathrm{~T}_{4}$ & $18.77 \mathrm{~b}$ & $9.67 \mathrm{c}$ & $263.40 \mathrm{~cd}$ & $21.50 \mathrm{de}$ & $70.19 \mathrm{e}$ & $8.77 \mathrm{e}$ \\
$\mathrm{M}_{2} \mathrm{~T}_{5}$ & $19.47 \mathrm{~b}$ & $12.13 \mathrm{c}$ & $331.16 \mathrm{~b}$ & $26.20 \mathrm{ab}$ & $151.35 \mathrm{~b}$ & $18.90 \mathrm{~b}$ \\
$\mathrm{M}_{2} \mathrm{~T}_{6}$ & $16.56 \mathrm{~d}$ & $11.89 \mathrm{c}$ & $266.83 \mathrm{~cd}$ & $17.73 \mathrm{fgh}$ & $66.98 \mathrm{e}$ & $8.37 \mathrm{e}$ \\
$\mathrm{M}_{2} \mathrm{~T}_{7}$ & $16.11 \mathrm{~d}$ & $10.00 \mathrm{C}$ & $163.73 \mathrm{ef}$ & $16.89 \mathrm{gh}$ & $59.49 \mathrm{e}$ & $7.43 \mathrm{e}$ \\
\hline $\mathrm{F}-\mathrm{test}$ & $* *$ & $* *$ & $* *$ & $* *$ & $* *$ & $* *$ \\
$\mathrm{CV}(\%)$ & 4.08 & 876 & 5.3 & 5.36 & 9.35 & 8.04 \\
\hline
\end{tabular}

In a column, the figure(s) having same letter(s) do not differ significantly by DMRT

** Significant at $1 \%$ level 
The highest leaf yield per plant was obtained from $\mathrm{M}_{1} \mathrm{~T}_{5}$ (192.32 g) and lowest was found in $\mathrm{M}_{2} \mathrm{~T}_{3}$ (17.73 g). The highest leaf yield per ha in $\mathrm{M}_{1} \mathrm{~T}_{5}$ (24.0 t), which was statistically different from all other interaction effects. The second highest yield was recorded in $\mathrm{M}_{2} \mathrm{~T}_{3}$ (20.39 t/ha), which was followed by $\mathrm{M}_{1} \mathrm{~T}_{4}$ (20.30 t/ha), $\mathrm{M}_{1} \mathrm{~T}_{1}(19.20 \mathrm{t} / \mathrm{ha})$, and $\mathrm{M}_{2} \mathrm{~T}_{5}(18.30 \mathrm{t} / \mathrm{ha})$. Direct sown plants performed better due to normal growth of the tap root and prevailing favourable environmental conditions during vegetative growth and development stage. The lowest leaf yield was observed in $\mathrm{M}_{2} \mathrm{~T}_{3}(2.23 \mathrm{t} / \mathrm{ha}$ ). The lowest leaf yield from transplanted plants in 27 November planting is probably due to the presence of low temperature and continuous foggy weather during the establishment of lettuce seedlings. It was revealed that the directly sown plants in all planting dates performed better in respect of leaf yield and all yield contributing characters.

The results led to conclude that the lettuce cultivar (Green Wave) may be sown during October to January for acceptable yields. Later planting will reduce the yield unless the variety is highly heat tolerant.

\section{References}

Burdine, T.K. and C.A. Sanchez. 1990. Response of four lettuce cultivars to temperature and day length. Proc. Soil Crop-Sci. Soc. Florida 49: 91-94.

Price, R. P, J. W. Bartok and D. W. Protheroe. 1981. Lettuce production in controlled environment plant growth unit ASAE 24(3): 725-730.

Rashid, M. M. 1999. Sabji Biggan (in Bengali). Rashid Publishing House. p. 526.

Ryder, E. J. 1998. Lettuce, Endive and Chicory. CABI Publishing Company, USA. p. 79.

Verkerk, K. and C. J. T. Spitters. 1973. Effects of light and temperature on lettuce seedlings. Netherlands Journal of Agricultural Science 21: 102-109. 